\title{
Understanding ternary poly(potassium benzimidazolide)-based polymer electrolytes
}

Aili, David; Jankova Atanasova, Katja ; Han, Junyoung; Bjerrum, Niels J.; Jensen, Jens Oluf; Li, Qingfeng

\section{Published in:}

Polymer

Link to article, DOI:

10.1016/j.polymer.2016.01.011

Publication date:

2016

Document Version

Peer reviewed version

Link back to DTU Orbit

Citation (APA):

Aili, D., Jankova Atanasova, K., Han, J., Bjerrum, N. J., Jensen, J. O., \& Li, Q. (2016). Understanding ternary poly(potassium benzimidazolide)-based polymer electrolytes. Polymer, 84, 304-310.

https://doi.org/10.1016/j.polymer.2016.01.011

\section{General rights}

Copyright and moral rights for the publications made accessible in the public portal are retained by the authors and/or other copyright owners and it is a condition of accessing publications that users recognise and abide by the legal requirements associated with these rights.

- Users may download and print one copy of any publication from the public portal for the purpose of private study or research.

- You may not further distribute the material or use it for any profit-making activity or commercial gain

- You may freely distribute the URL identifying the publication in the public portal

If you believe that this document breaches copyright please contact us providing details, and we will remove access to the work immediately and investigate your claim 


\title{
Understanding ternary poly(potassium benzimidazolide)-based
}

\section{polymer electrolytes}

David Aili,* Katja Jankova, Junyoung Han, Niels J. Bjerrum, Jens Oluf Jensen, and Qingfeng Li

Department of Energy Conversion and Storage, Technical University of Denmark, Kemitorvet 207, DK-2800 Kgs.

Lyngby, Denmark

\begin{abstract}
Poly(2,2'-( $m$-phenylene)-5,5'-bisbenzimidazole) ( $m$-PBI) can dissolve large amounts of aqueous electrolytes to give materials with extraordinary high ion conductivity and the practical applicability has been demonstrated repeatedly in fuel cells, water electrolysers and as anion conducting component in fuel cell catalyst layers. This work focuses on the chemistry of $m$-PBI in aqueous potassium hydroxide. Equilibration in aqueous $\mathrm{KOH}$ with concentrations of $15-20 \mathrm{wt} \%$ was found to result in ionization of the polymer, causing released intermolecular hydrogen bonding. This allowed for extensive volume swelling, dramatic plasticization and increase of the ion conductivity for the formed poly(potassium benzimidazolide)-based structure. Further increasing the concentration of the bulk solution to 50 wt. $\%$ resulted in dehydration and extensive crystallization of the polymer matrix as evidenced by X-ray diffraction, increased density and enhanced elastic modulus.
\end{abstract}

Keywords: polybenzimidazole, ionomer, alkaline, ion-solvation, electrolyte

* Corresponding author. Telephone: +45 45252413; Fax: +45 45883136; E-mail: larda@dtu.dk 


\section{Introduction}

Polybenzimidazoles comprise a class of amphoteric polymers used in demanding applications requiring excellent thermo-mechanical stability [1]. Poly(2,2'-( $m$-phenylene)-5,5'-bisbenzimidazole) ( $m$-PBI, Figure 1) is the most widely used derivative and it is synthesized by melt condensation polymerization [2] or more commonly by homogenous solution polymerization in polyphosphoric acid [3] from 3,3'diaminobenzidine and isophthalic acid. It is a highly hygroscopic polymer, showing water uptake typically around $15 \mathrm{wt} . \%$ [4], corresponding to about 3 water molecules per polymer repeat unit. It strongly interacts with ionic species [5], and the imidazole moieties are readily protonated in the presence of protic acids (Figure 1, top) to give polymer matrices with high proton conductivity [6]. Of the different acids, $\mathrm{H}_{3} \mathrm{PO}_{4}$ is of particular interest as dopant due to its low vapor pressure and high intrinsic proton conductivity at temperatures well above $100{ }^{\circ} \mathrm{C}$ [7]. During the last two decades this electrolyte system has been thoroughly characterized with respect to e.g. the chemistry of acid uptake and proton transport [8-14], thermal [15] and chemical stability [16, 17], nanostructure [18] as well as gas permeability [19]. Furthermore, many new polybenzimidazole chemistries [20] and polymer blend systems [21] have been developed.

The weakly acidic imidazole protons of $m$-PBI can be subtracted if a strong base (such as an alkali metal hydroxide, alkoxide or hydride) is used to form a polyanion, as shown in Figure 1 (bottom). Such poly(benzimidazolide)s are strongly nucleophilic and are used as intermediates in the synthesis of Michael addition type crosslinked $m$-PBI [22] or poly(alkyl/aryl benzimidazolium) ionomers [23-26]. The $N$-functionalized polybenzimidazoles have recently been explored as potential anion conductors [2729] or as a component in phosphoric acid doped polymer blends [30]. In this connection, significant 
chemical stability improvements have been achieved by means of steric [31, 32] or electronic [33] optimization of the polymer backbone.
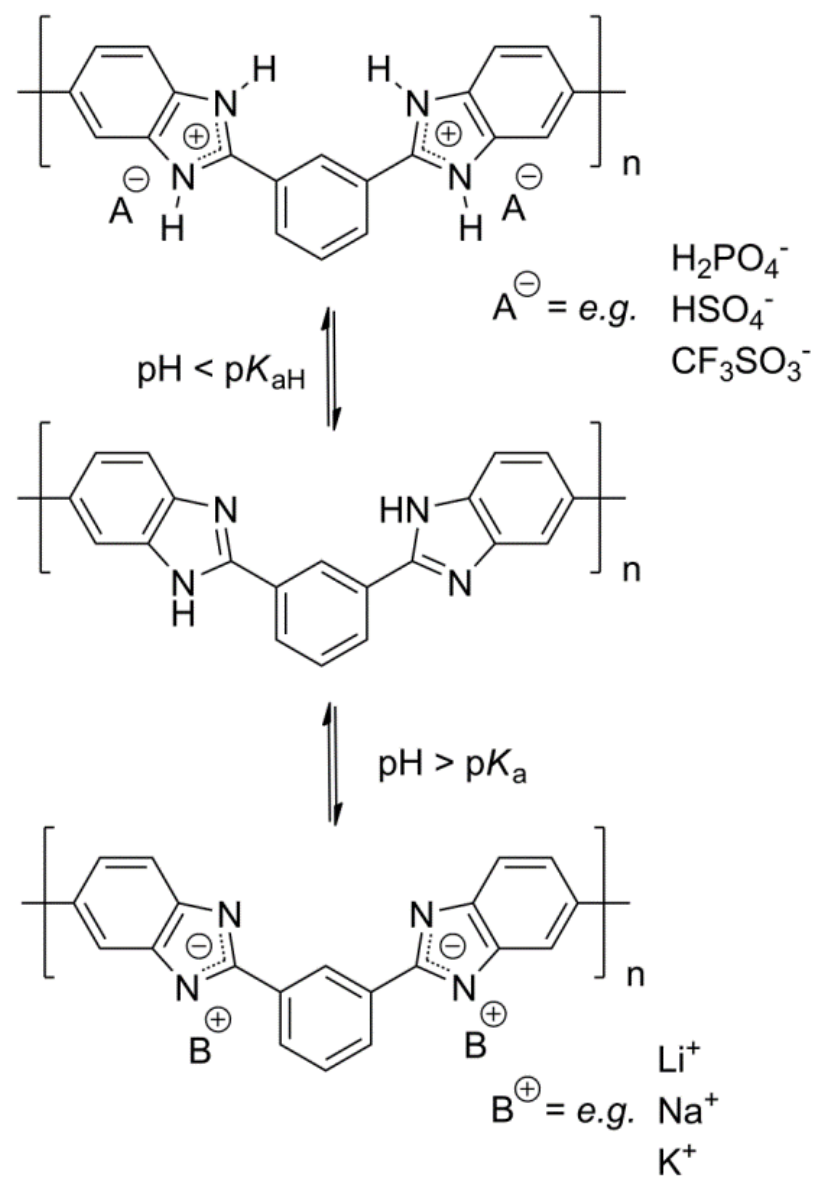

Figure 1 Schematic illustration showing the amphoteric nature of $m$-PBI and the protonation and deprotonation of the benzimidazole moieties in acidic (top) and basic (bottom) environment, respectively.

Alternatively, the pristine form of $m$-PBI can be equilibrated in aqueous solutions of alkali metal hydroxides to form apparently homogenous ternary systems composed of the hydroxide salt and water dissolved in the polymer matrix. Such semi-solid materials exhibit remarkably high ion conductivity 
[34], excellent chemical stability at low alkali concentrations [35] and have been tested as electrolytes in hydrogen [34, 36, 37] and direct alcohol [38-42] fuel cells, water electrolysers [43, 44] and as anion conducting phase in alkaline fuel cell catalyst layers [45-47]. Despite the recent efforts to develop electrochemical systems around this electrolyte system, the physicochemical chemistry of polybenzimidazoles in alkaline environment remains unexplored to a large extent. In this work, a combination of techniques was employed to study the physicochemical properties of thin films of $m$-PBI in aqueous $\mathrm{KOH}$ of concentrations ranging from $0-50 \mathrm{wt} . \%$. The ionized form of the polymer was found to predominate at $\mathrm{KOH}$ concentrations higher than $15-20 \mathrm{wt} . \%$, which resulted in released intermolecular hydrogen bonding, high swelling, significant plasticization and enhanced ion conductivity. Further increasing the concentration of $\mathrm{KOH}$ in the bulk solution resulted in dehydration and crystallization of the polymer matrix.

\section{Experimental}

\subsection{Materials}

The inherent viscosity $\eta_{\text {inh }}$ of $m$-PBI (Danish Power Systems ApS), as determined in 96 wt. $\% \mathrm{H}_{2} \mathrm{SO}_{4}$ at $30.0{ }^{\circ} \mathrm{C}$ (solid content $500 \mathrm{mg} \mathrm{dL}^{-1}$ ) using an Ubbelohde capillary viscosimeter, was $0.95 \mathrm{dL} \mathrm{g}^{-1}$. The polymer was dissolved in $\mathrm{N}, \mathrm{N}$-dimethylacetamide (DMAc) $(6.1 \mathrm{wt} . \%$ solid content) and cast on partly covered Petri dishes $\left(11 \mathrm{~cm}\right.$ diameter) from room temperature to $120^{\circ} \mathrm{C}$ at $7{ }^{\circ} \mathrm{C} \mathrm{h}^{-1}$. The $m$-PBI films were delaminated from the glass substrates in demineralized water and further treated with demineralized water for $4 \mathrm{~h}$ at $95^{\circ} \mathrm{C}$ and dried at $150^{\circ} \mathrm{C}$ for at least $4 \mathrm{~h}$. The aqueous $\mathrm{KOH}$ solutions with concentrations of $5,10,15,20,25,35$ and $50 \mathrm{wt} . \%$ (corresponding to $0.9,1.9,3.0,4.2,5.5,8.4$ and $13.4 \mathrm{~mol} \mathrm{~L}^{-1}$, respectively) were prepared by dissolving $\mathrm{KOH}$ pellets (Sigma-Aldrich) in demineralized water and the 
concentrations were confirmed by density measurements at room temperature $(1.04,1.08,1.13,1.18$, $1.25,1.36$ and $1.52 \mathrm{~g} \mathrm{~mL}^{-1}$, respectively) which were compared with literature data [48].

\subsection{Characterization}

The weight and dimensional changes were recorded for a total of 8 square-shaped samples per $\mathrm{KOH}$ concentration (initial area $15-20 \mathrm{~mm} \times 15-20 \mathrm{~mm}$, initial thickness 30-40 $\mu \mathrm{m}$ ), in 2 separate series of experiments. The samples were individually marked and dried at $150{ }^{\circ} \mathrm{C}$ for at least $4 \mathrm{~h}$ before the weight and dimensions were recorded. The samples were subsequently kept in sealed poly(tetrafluoroethylene) (PTFE) bottles filled with aqueous $\mathrm{KOH}$ for about $16 \mathrm{~h}$ at $90{ }^{\circ} \mathrm{C}$. The solutions were cooled to room temperature and the weight and dimensions of the individual samples were recorded after careful blotting with tissue paper. The weight and dimensional changes were calculated on the basis of the dry pristine material. The compositions were determined gravimetrically as described elsewhere [35, 43] and by $\mathrm{pH}$ titration with a $0.01 \mathrm{~mol} \mathrm{~L}^{-1} \mathrm{HCl}$ (aq.) standard solution (Sigma-Aldrich) on approximately $30 \mathrm{mg}$ of the $\mathrm{KOH}$ doped $m$-PBI after stirring in $30 \mathrm{~mL}$ demineralized water for at least 15 minutes. The samples were washed extensively with demineralized water after the titration, dried at $110{ }^{\circ} \mathrm{C}$ in vacuo for $2 \mathrm{~h}$ for the determination of the polymer weight fraction.

The Fourier transform infrared (FTIR) spectra were recorded using a Perkin Elmer Spectrum Two equipped with an attenuated total reflectance (ATR) accessory. X-ray diffraction (XRD) was carried out using a Rigaku MiniFlex 600 using a Cu $\mathrm{K}_{\alpha}$ X-ray source with a wavelength $\lambda$ of $1.5418 \AA$. The $d$ spacings for the amorphous or crystalline peak maxima were calculated according to the Bragg equation. ${ }^{1} \mathrm{H}$-nuclear magnetic resonance $\left({ }^{1} \mathrm{H}-\mathrm{NMR}\right)$ spectra were recorded on a Bruker Ascend at an operating frequency of $400 \mathrm{MHz}$. Deuterated dimethylsulfoxide (DMSO- $d_{6}$ ) was used as solvent and the solvent residual signal at $2.50 \mathrm{ppm}$ was used as reference. The stress-strain curves were recorded using a 
Testometric Micro 350 at crosshead speed of $10.00 \mathrm{~mm} \mathrm{~min}^{-1}$, using dog-bone shaped specimens (30 $\mathrm{mm}$ between the shoulders and $2.0 \mathrm{~mm}$ wide) prepared by die-cutting in a hydraulic press. Scanning electron microscopy (SEM) was carried out on a Carl Zeiss EVO MA10 equipped with an INCA EDS system from Oxford Instruments. The samples were prepared by sandwiching the polymer films between two pieces of non-woven carbon cloth followed by ion-milling using a Hitachi E-3500, and subsequently sputter-coated with carbon.

The ion conductivity was measured in a tubular (inner diameter $0.9 \mathrm{~cm}$ ) cell composed of two separate blocks made of PTFE. Electrodes made of nickel mesh with point welded wires for electrical connections were fixed using PTFE gaskets, which also fixed the distance between the electrodes in the cell assembly to $2.0 \mathrm{~mm}$. The resistance between the electrodes, taken as $Z_{\mathrm{re}}$ at $Z_{\mathrm{im}}=0$, was recorded by electrochemical impedance spectroscopy, using a VersaStat 3 from Princeton Applied Research. The cell was calibrated using a set of $\mathrm{KCl}$ (aq.) conductance standards from Sigma-Aldrich. The ion conductivity $\sigma$ of the polymer film was calculated according to Equation 1, where $t$ is the thickness of the polymer film, $R$ is the measured resistance with the polymer film mounted between the electrodes, $R_{\text {blank }}$ is the resistance of the electrolyte filling up the gap between the polymer film and electrode (1.0 mm on each side) and $A$ is the cross-sectional area of the cell $\left(0.636 \mathrm{~cm}^{2}\right)$. The standard deviation for $R$ and $R_{b l a n k}$ was generally well below $3 \%(n=4)$.

$\sigma=t /\left(\left(R-R_{\text {blank }}\right) \times A\right)$

\section{Results and discussion}


When equilibrated in aqueous $\mathrm{KOH}$, the electrolyte dissolves and evenly distributes in the $m$-PBI matrix as indicated by the homogeneous $\mathrm{K}$ and $\mathrm{O}$ distribution at a scale of about $1 \mu \mathrm{m}$ in the cross-sectional EDS maps (Figure 2). In this regard it resembles the ion-solvating polymers (e.g. polyethylene oxide) commonly used as electrolytes in different types of batteries, but is in contrast completely insoluble in water as discussed by Merle et al. [49].

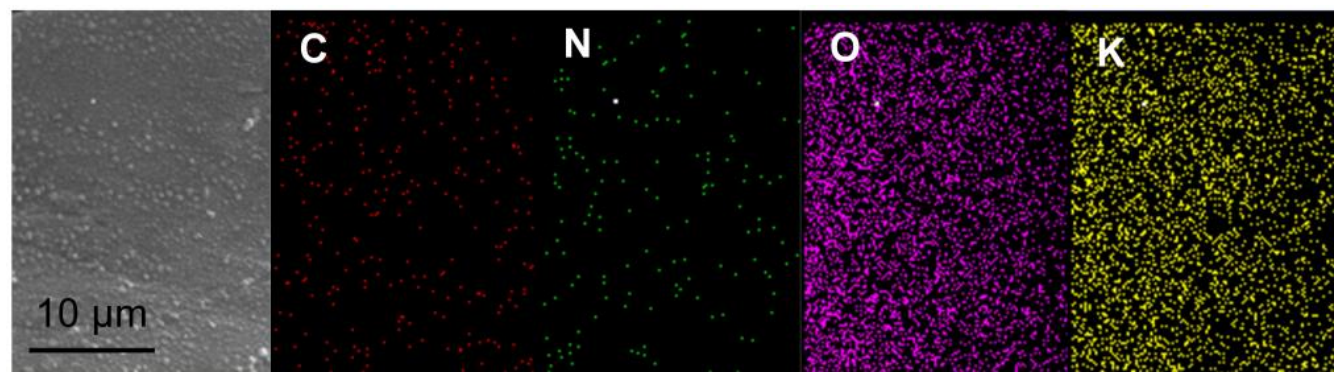

Figure 2 Cross-sectional SEM image (secondary) of $m$-PBI treated in $50 \mathrm{wt} \% \mathrm{KOH}$ (left) and corresponding EDS elemental mapping for carbon $(C)$, nitrogen $(N)$, oxygen $(O)$ and potassium $(K)$.

The weight gain of $m$-PBI due to uptake of water and $\mathrm{KOH}$ is known to increase with increasing $\mathrm{KOH}$ concentration of the bulk solution, but determining individual contribution from water and $\mathrm{KOH}$ is far from trivial. The polymer exhibits strong water affinity, absorbing about 3 water molecules per polymer repeat unit through hydrogen bonding with the imidazole moieties. $\mathrm{KOH}$ is also highly hygroscopic and form a series of crystalline hydrates in the solid state, which readily dissociate to various hydrated complexes such as $\left(\mathrm{H}_{9} \mathrm{O}_{5}\right)^{-}$or $\left(\mathrm{H}_{13} \mathrm{O}_{7}\right)^{-}$when dissolved in water [50]. The degree of ionization of $m$ $\mathrm{PBI}$, i.e. the position of the acid-base equilibrium, depends on the $\mathrm{KOH}$ concentration and gravimetric approaches for the composition determination are therefore complicated by the fact that the effective $\mathrm{KOH}$ concentration increases during drying $[35,42,43]$. It inevitably shifts the acid-base equilibrium 
(Figure 1) towards the poly(benzimidazolide) resulting in enhanced molar mass per repeat unit. Washing with water reverses the reaction, and the released aqueous $\mathrm{KOH}$ can be quantified by acid-base titration. According to this methodology the $\mathrm{KOH}$ equivalents per $m$-PBI repeat unit ( $m$-PBI $\mathrm{RU}$ ) for samples treated in different concentrations of aqueous $\mathrm{KOH}$ were determined, as summarized in Table 1 . The $\mathrm{KOH}$ content, normalized as $\mathrm{KOH}$ equivalents per polymer repeat unit, increased gradually with increasing concentration of the bulk solution reaching $2.6 \mathrm{KOH}$ per repeat unit at $25 \mathrm{wt} . \%$ bulk concentration. At the same time the water content was significantly increased from $3.0 \mathrm{H}_{2} \mathrm{O}$ per repeat unit in pure water to $9.7 \mathrm{H}_{2} \mathrm{O}$ per repeat unit in $10 \mathrm{wt} . \% \mathrm{KOH}$. The water content further increased to more than $20 \mathrm{H}_{2} \mathrm{O}$ per repeat unit when the $\mathrm{KOH}$ concentration of the bulk solution reached 20-25 wt.\%. At a bulk concentration of 5 wt. $\% \mathrm{KOH}$, the $\mathrm{H}_{2} \mathrm{O}$ to $\mathrm{KOH}$ molar ratio was 60 and 20 in the bulk solution and in the polymer phase, respectively. At a bulk concentration of $50 \mathrm{wt} \% \mathrm{KOH}$, the $\mathrm{H}_{2} \mathrm{O}$ to $\mathrm{KOH}$ molar ratio in the bulk solution and polymer phase were 3.2 and 5.5, respectively, apparently showing a concentrating effect of the polymer phase with respect to water in the higher $\mathrm{KOH}$ concentration regime. At bulk concentrations around 20-25 wt.\%, the $\mathrm{H}_{2} \mathrm{O}$ to $\mathrm{KOH}$ molar ratio in the bulk solution and in the polymer phase were found to be similar. The compositions were also calculated based entirely on gravimetric measurements as summarized in Figure S1 and were in good agreement with the data obtained from titration and consistent with the data available in the literature $[35,42,43]$.

Table 1 Calculated compositions based on acid-base titrations in combination with gravimetric measurements and ion conductivity $\sigma_{r t}$ at room temperature of the corresponding compositions. 


\begin{tabular}{|c|c|c|c|c|c|c|c|}
\hline \multicolumn{3}{|c|}{ Bulk solution } & \multicolumn{5}{|c|}{ Polymer phase } \\
\hline$[\mathrm{KOH}] /$ & $\mathrm{H}_{2} \mathrm{O}$ per & $\sigma_{r t} / \mathrm{mS} \mathrm{cm}^{-1}$ & Total uptake & $\mathrm{H}_{2} \mathrm{O}$ per $m-$ & $\mathrm{KOH}$ eq. per & $\mathrm{H}_{2} \mathrm{O}$ per $\mathrm{KOH}$ & $\sigma_{r t} / \mathrm{mS}$ \\
\hline wt. $\%$ & $\mathrm{KOH}$ & & / wt.\% & $\mathrm{PBI}_{\mathrm{RU}}$ & $m-\mathrm{PBI}_{\mathrm{RU}}$ & & $\mathrm{cm}^{-1}$ \\
\hline 0 & - & - & 17.5 & 3.0 & 0 & - & - \\
\hline 5 & 60.2 & 183 & 23.3 & 4.0 & 0.2 & 20.0 & 0.2 \\
\hline 10 & 28.5 & 310 & 56.5 & 9.7 & 0.7 & 14.9 & 9 \\
\hline 15 & 17.9 & 407 & 108.1 & 18.5 & 1.5 & 12.4 & 110 \\
\hline 20 & 12.7 & 491 & 127.4 & 21.8 & 1.8 & 12.4 & 130 \\
\hline 25 & 9.5 & 523 & 134.2 & 23.0 & 2.6 & 9.0 & 84 \\
\hline 35 & 5.0 & 465 & 99.3 & 17.0 & 2.5 & 6.8 & 52 \\
\hline 50 & 3.2 & 324 & 89.7 & 15.3 & 2.8 & 5.5 & 13 \\
\hline
\end{tabular}

At room temperature, the ion conductivity of the polymer phase reached as high as $130 \mathrm{mS} \mathrm{cm}^{-1}$ in 20 wt.\% aqueous $\mathrm{KOH}$ (Table 1). For comparison, the ion conductivity of the bulk solution peaked at a concentration of $25 \mathrm{wt} . \%$, where it reached $523 \mathrm{mS} \mathrm{cm}^{-1}$. Considering practical aspects with respect to the use in electrochemical cells and corrosion of system auxiliary units, it is a clear advantage that lower $\mathrm{KOH}$ concentrations can be used without increasing the internal resistance.

An apparent observation after the treatment in aqueous $\mathrm{KOH}$ was the anisotropic swelling behavior, as summarized in Figure 3, and as also recently reported Zeng et al. [51] as well as by Couto and Linares [42]. Up to a $\mathrm{KOH}$ bulk solution concentration of $15 \mathrm{wt} \%$, the thickness as well as the surface area increased with increasing concentration. Further increasing the KOH bulk concentration to 20-25 wt.\% resulted in a dramatic shrinkage in surface area and a significant thickness increase. For comparison, the swelling behavior of $m$-PBI in $\mathrm{H}_{3} \mathrm{PO}_{4}$ is practically isotropic [52]. 


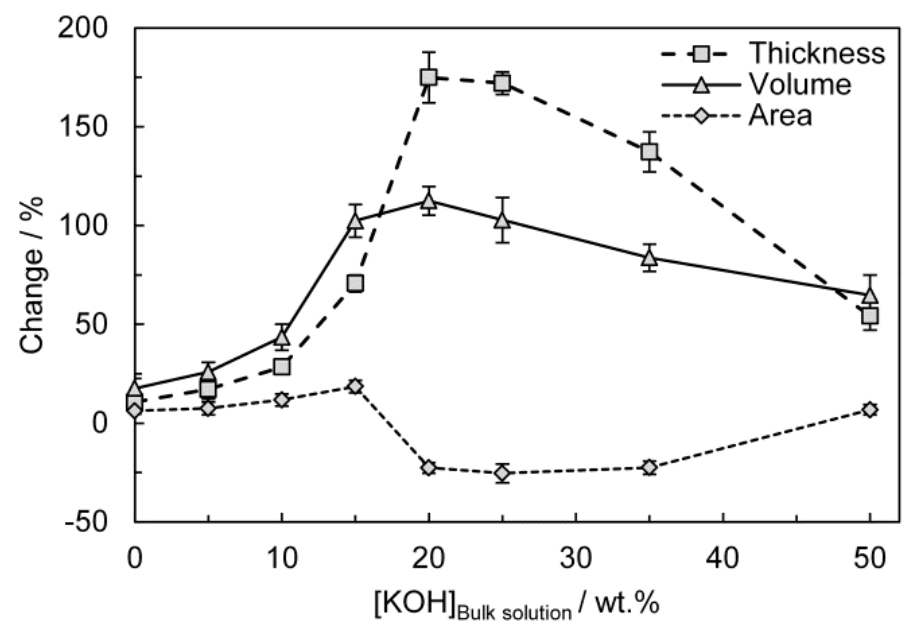

Figure 3 Area, thickness and volume after equilibration in aqueous $\mathrm{KOH}$ of different concentrations, expressed relative to the dry pristine material.

Searching for a molecular explanation to the peculiar swelling behavior that was observed on a macroscopic scale, the materials were investigated by X-ray diffraction (XRD), as shown in Figure 4. The broad peak at around $2 \theta=11.5^{\circ}$ was due to background diffraction from the silicone grease used to protect the sample holder ( $\mathrm{Si}$-wafer) from the highly corrosive samples. The $m$-PBI that had been equilibrated in pure water showed a broad amorphous peak around $2 \theta=25^{\circ}$, in consistence with diffraction data in the literature $[19,53,54]$. The corresponding $d$-spacing was $3.54 \AA$ (Table 2 ), which is considerably smaller than for many other common polymers and due to the extensive hydrogen bonding network resulting in close chain packing [19]. The intensity of the amorphous peak decreased when the $\mathrm{KOH}$ concentration of the bulk solution was increased to $15 \mathrm{wt} \%$, likely due to the polymer chain separation as a result of the extensive electrolyte uptake. It is obvious that within the layered structure the interlayer molecular force is smaller than the intra-layer one. This explains the observation that the membrane displayed a significant growth in the thickness accompanied with a slow increase of 
the surface area in the low $\mathrm{KOH}$ concentration range. When equilibrated in $20-25$ wt.\% $\mathrm{KOH}$ full ionization of the polymer is approached (see discussion on FTIR later), resulting in a sudden increase of the thickness accompanied by an area decrease and decreased water content. When the $\mathrm{KOH}$ concentration of the bulk solution was further increased to $50 \mathrm{wt} . \%$, sharp reflections at $2 \theta=12.88$, 25.83, 32.72 and $39.14^{\circ}$ appeared, corresponding to $d$-spacings of $6.87,3.45,2.74$ and $2.30 \AA$, respectively, which in turn correspond to certain interlayer distances in a lattice structure. The sharp reflections observed after equilibration in $\mathrm{KOH}$ in the higher concentration range have previously been assigned to free $\mathrm{KOH}$ within the polymer matrix [38, 42]. However, pure $\mathrm{KOH}$ and the known $\mathrm{KOH}$ hydrates show more complex diffraction patterns and the sharp crystalline reflections are thus more likely due to a crystalline phase of a poly(potassium benzimidazolide) hydrate. The diffraction pattern with only four sharp and intense reflections indicates a symmetric and highly regular structure with crystallite size in the range of 70-120 $\mathrm{nm}$ as calculated from the four sharp reflections according to the Scherrer equation. After washing with demineralized water until neutral $\mathrm{pH}$ the crystalline reflections vanished (see Figure S2). This phenomenon is similar to the pronounced crystallization observed in the poly(ethylene oxide)- $\mathrm{KOH}-\mathrm{H}_{2} \mathrm{O}$ system when the concentration of the bulk solution is increased [55]. 


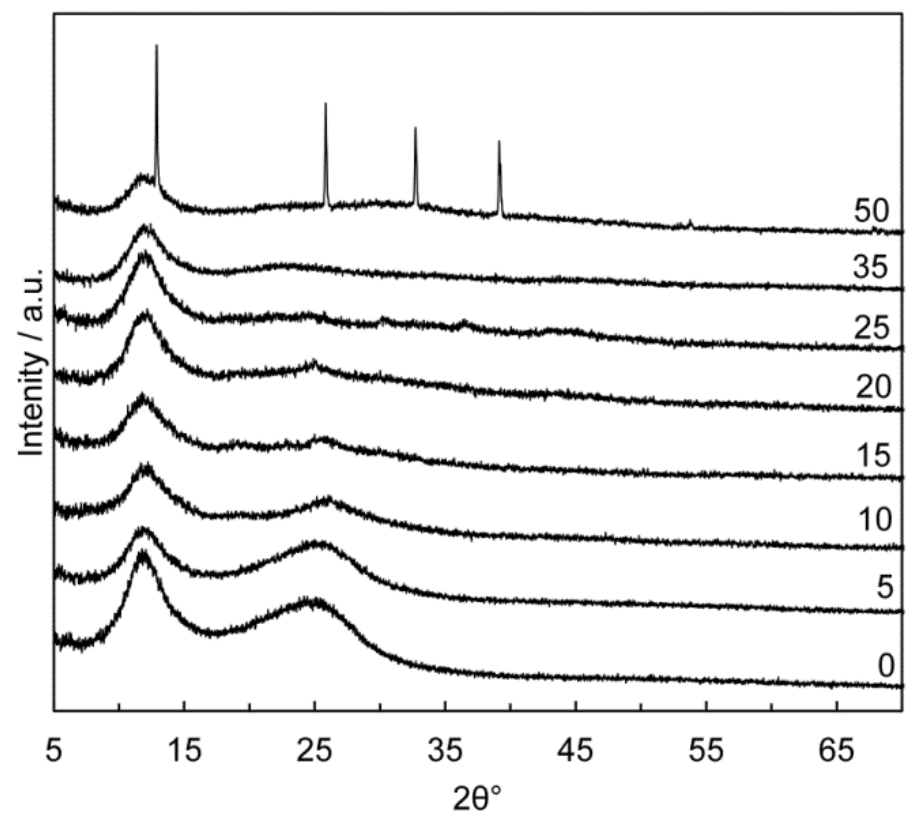

Figure 4 XRD of $m$-PBI equilibrated in aqueous $\mathrm{KOH}$ of concentrations ranging from $0-50 \mathrm{wt} . \%$. The broad peak at around $2 \theta=11.5^{\circ}$ is due to background diffraction from the silicone grease used to protect the sample holder ( $\mathrm{Si}$-wafer) from the highly corrosive samples. 
Table 2 Summary of X-ray diffraction data and the corresponding $d$-spacings and measured densities.

\begin{tabular}{llll}
\hline$[\mathrm{KOH}] /$ wt. $\%$ & $2 \theta^{\circ}$ & $\rho / \AA$ & \multicolumn{1}{c}{$\mathrm{g} \mathrm{cm}^{-3}$} \\
\hline 0 & 25.16 & 3.54 & 1.32 \\
5 & 25.00 & 3.56 & 1.36 \\
10 & 25.68 & 3.47 & 1.47 \\
15 & - & - & 1.53 \\
20 & - & - & 1.40 \\
25 & - & - & 1.46 \\
35 & - & - & 1.50 \\
& 12.88 & 6.87 & \\
& 25.83 & 3.45 & 1.53 \\
50 & 32.72 & 2.74 & \\
\hline
\end{tabular}

The $m$-PBI that had been equilibrated in pure water showed typical $[35,43]$ stress-strain behavior as shown in Figure 5, and engineering tensile strength of around $130 \mathrm{MPa}$, elongation at break of $80 \%$ and an elastic modulus of $3.0 \mathrm{GPa}$. The mechanical strength of a polymer is due to attractive intermolecular forces and for pure $m$-PBI, the hydrogen bonding between imidazole moieties are dominating [56]. Introduction of species that interact with the imidazole groups through hydrogen bonding reduces the molecular cohesion. The strong plasticizing effect of water and $\mathrm{KOH}$ resulted in a dramatic decay of the engineering tensile strength and elastic modulus and enhanced elongation at break when the $\mathrm{KOH}$ concentration of the bulk solution was increased. Ionization of the polymer further promoted this mechanism due to the released intermolecular hydrogen bonding, which is otherwise responsible for the mechanical strength of the pristine material. When the concentration of the bulk solution was increased 
to 20-25 wt.\%, full ionization of the polymer was reached (see discussion on FTIR later), showing pronounced plastic behavior and permanent deformation at low stress and more than $200 \%$ elongation at break. By further increasing the concentration of the bulk solution to $50 \mathrm{wt} . \%$, the elastic modulus increased to $1.4 \mathrm{GPa}$ as compared to $0.3 \mathrm{GPa}$ in $25 \mathrm{wt} . \% \mathrm{KOH}$ further indicating a high degree of crystallinity [57].

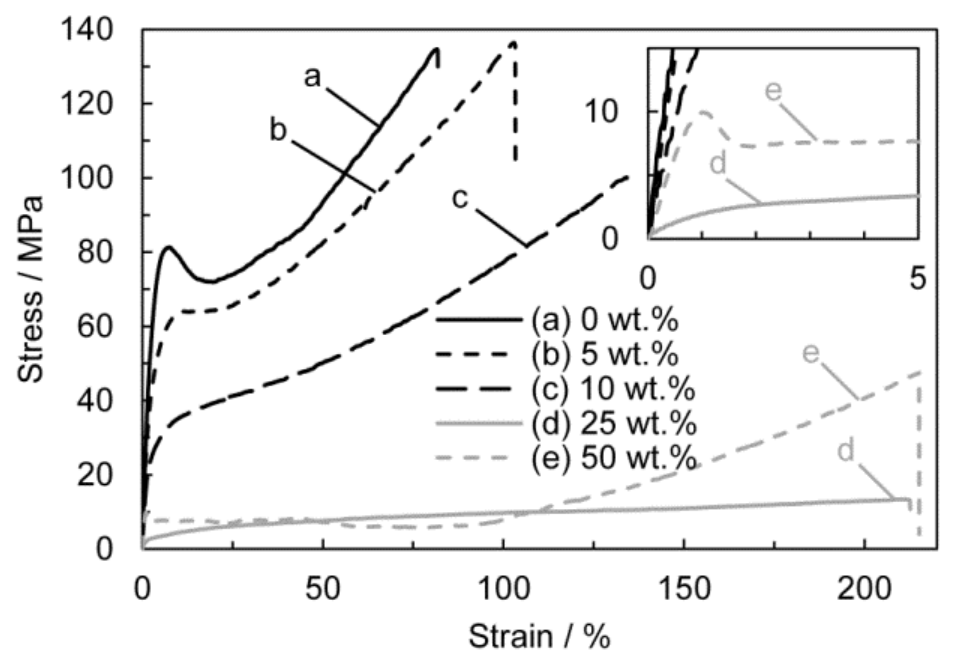

Figure 5 Representative stress-strain curves after equilibration in aqueous $\mathrm{KOH}$ of different concentrations.

The $m$-PBI that had been equilibrated in pure water showed the typical FTIR spectral features as reported and assigned elsewhere (Figure 6a) $[6,8,58,59]$. Of special interest are the characteristic absorption bands at 1440 and $1540 \mathrm{~cm}^{-1}$, which originate from the in-plane ring vibration of the benzimidazole moieties [59]. Equilibration in aqueous $\mathrm{KOH}$ strongly reduced the intensity of these absorption bands while new absorption bands at 1550 and $1413 \mathrm{~cm}^{-1}$ appeared. Furthermore, new absorption bands at 1315,1365 and $1602 \mathrm{~cm}^{-1}$ appeared at $\mathrm{KOH}$ concentrations of $10 \mathrm{wt} . \%$ and higher and a new band at 
$1480 \mathrm{~cm}^{-1}$ appeared when the $\mathrm{KOH}$ concentration reached $25 \mathrm{wt} . \%$. It clearly shows that the chemical environment of the benzimidazole moieties was strongly affected as a result of the dissociation of the acidic proton. Changes in the fingerprint region were also observed while the low frequency range (2300$3700 \mathrm{~cm}^{-1}$ ) was dominated by the strong bands from the absorbed water and excess hydroxide ions (not shown).

After drying at $150{ }^{\circ} \mathrm{C}$ for $3 \mathrm{~h}$, the strong broad $-\mathrm{OH}$ band $\left(2300-3700 \mathrm{~cm}^{-1}\right)$ due to water could no longer be observed and the characteristic absorption band at $3415 \mathrm{~cm}^{-1}$ due to free $\mathrm{N}-\mathrm{H}$ stretching [4, 59] became visible for the pristine $m$-PBI (Figure 6b). At higher KOH concentrations than $15 \mathrm{wt} . \%$ the $\mathrm{N}-\mathrm{H}$ stretching band disappeared. Furthermore, the broad absorption band located around $3100 \mathrm{~cm}^{-1}$ assigned to self-associated hydrogen bonded $\mathrm{N}-\mathrm{H}$ groups [60] disappeared. At the same time, the benzimidazole in-plane vibration band $\left(1440 \mathrm{~cm}^{-1}\right)$ and the imidazole ring breathing at $\left(1282 \mathrm{~cm}^{-1}\right)$ [59] disappeared and a new absorption band at $1375 \mathrm{~cm}^{-1}$ appeared.

Altogether the FTIR data indicate a significant change of the chemical environment of the benzimidazole moieties, likely induced by the deprotonation of the imidazole groups as also discussed recently [42]. Based on the FTIR spectral data it seems likely that the fully ionized form of $m$-PBI predominates at $\mathrm{KOH}$ concentrations of the bulk solution higher than around $15-20$ wt. $\%$, where significant changes in the spectra were observed. 

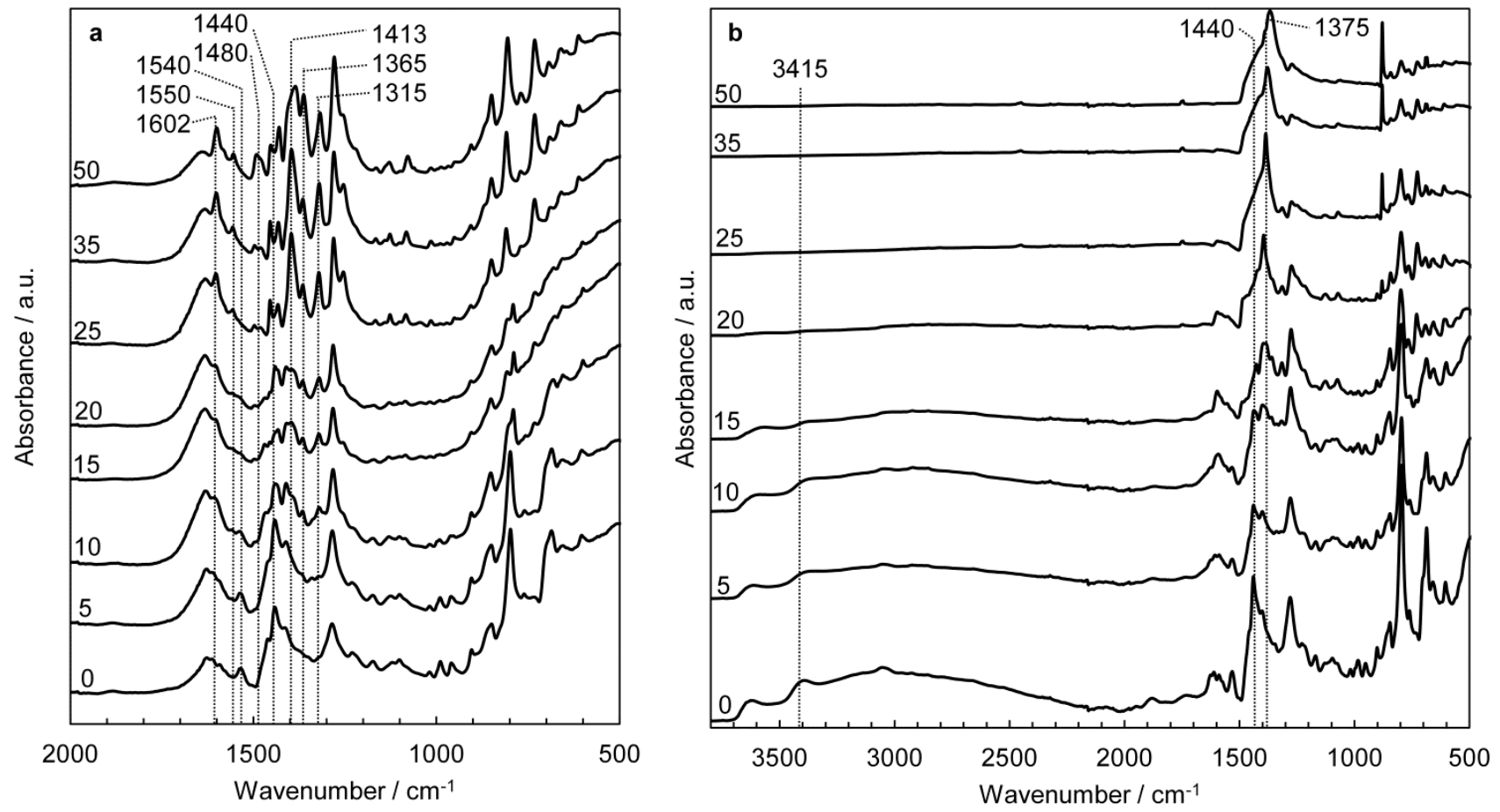

Figure 6 ATR-FTIR spectra of $m$-PBI equilibrated in aqueous KOH of concentrations ranging from 0-

$50 \mathrm{wt} . \%$ before (a) and after (b) drying at $150{ }^{\circ} \mathrm{C}$ for $3 \mathrm{~h}$.

The ${ }^{1} \mathrm{H}-\mathrm{NMR}$ spectrum of the pristine $m$-PBI was dominated by signals in the aromatic region as previously assigned in the literature [31, 61] (Figure 7). The signal of the $-\mathrm{NH}$ group $\left(\mathrm{H}_{\mathrm{a}}\right)$ of the benzimidazole moiety at $13.3 \mathrm{ppm}$ disappeared in the spectrum of the $m$-PBI that had been equilibrated in $50 \mathrm{wt} . \%$, indicating complete ionization. All the signals from the aromatic protons (except the singlet at $9.15 \mathrm{ppm}$ ) showed upfield shifts relative to the pristine $m$-PBI, indicating increased shielding. It can be explained by the increased electron density of the aromatic system due to the ionization of the polymer. 

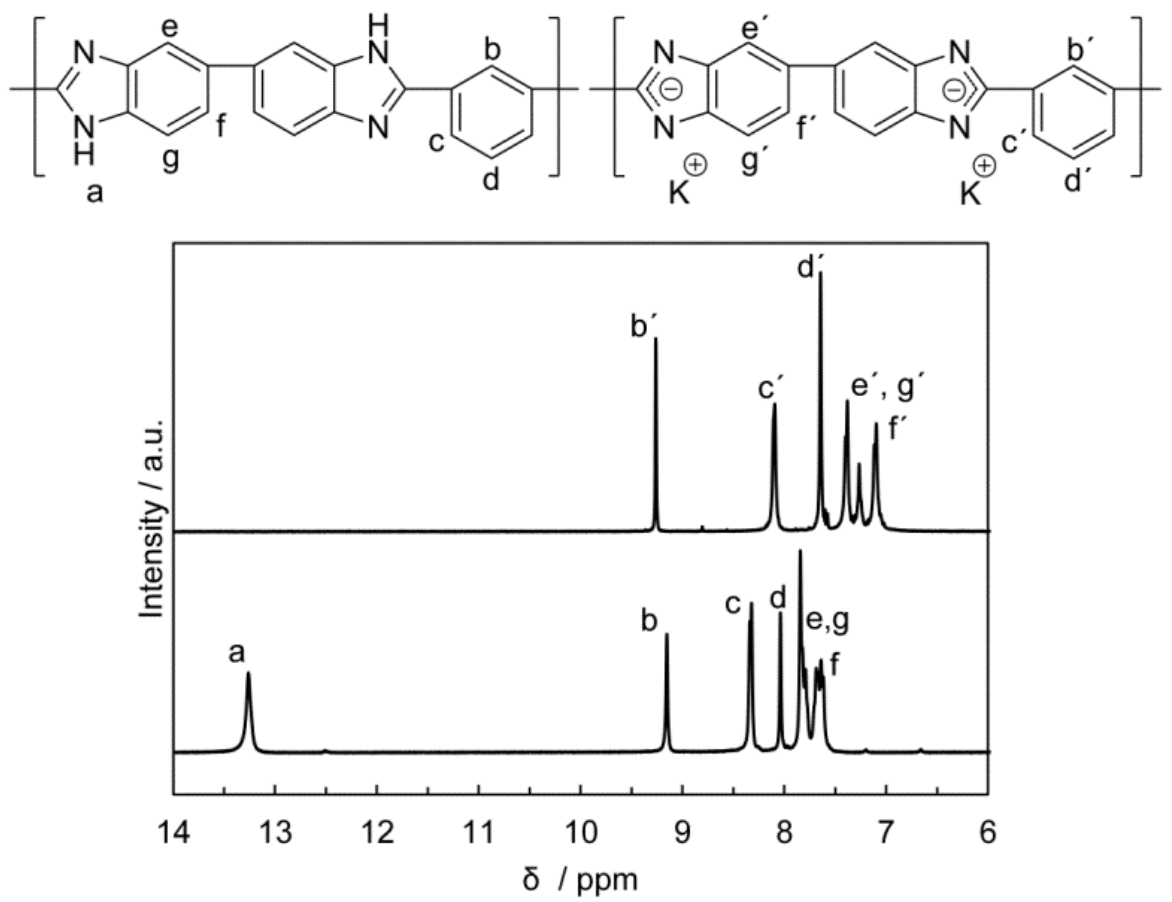

Figure $7{ }^{1} \mathrm{H}$-NMR of pristine $m$-PBI (bottom) and of $m$-PBI equilibrated in 50 wt.\% aqueous KOH (top). The peak assignment for pristine $m$-PBI as reported by Thomas et al. [31].

In summary, the spectroscopic data indicate that the deprotonated form of $m$-PBI, poly(potassium(2,2'(m-phenylene)-5,5'-bisbenzimidazolide)), predominates when the $\mathrm{KOH}$ concentration of the bulk solution reaches $15-20 \mathrm{wt} . \%$. This is also the concentration region where a sudden increase in thickness and decrease in surface area and a local density minimum can be observed. The full ionization of the polymer releases the extensive hydrogen intermolecular bonding, which in turn allows for extensive swelling of the polymer matrix, extraordinary high water and $\mathrm{KOH}$ uptake, and therefore a maximum in ion conductivity, dramatically reduced tensile strength and increased plasticity. Further increasing the $\mathrm{KOH}$ concentration to $50 \mathrm{wt} . \%$ resulted in decreased water content and increased $\mathrm{KOH}$ content, which likely induced the extensive crystallization of the polymer matrix characterized by high density and 
dramatically increased elastic modulus. The crystal structure of the poly(potassium $\left(2,2^{\prime}\right.$-( $m$-phenylene)5,5'-bisbenzimidazolide) or the hydrate thereof remains a subject for further investigation but a schematic illustration of the material is given in Figure 8.

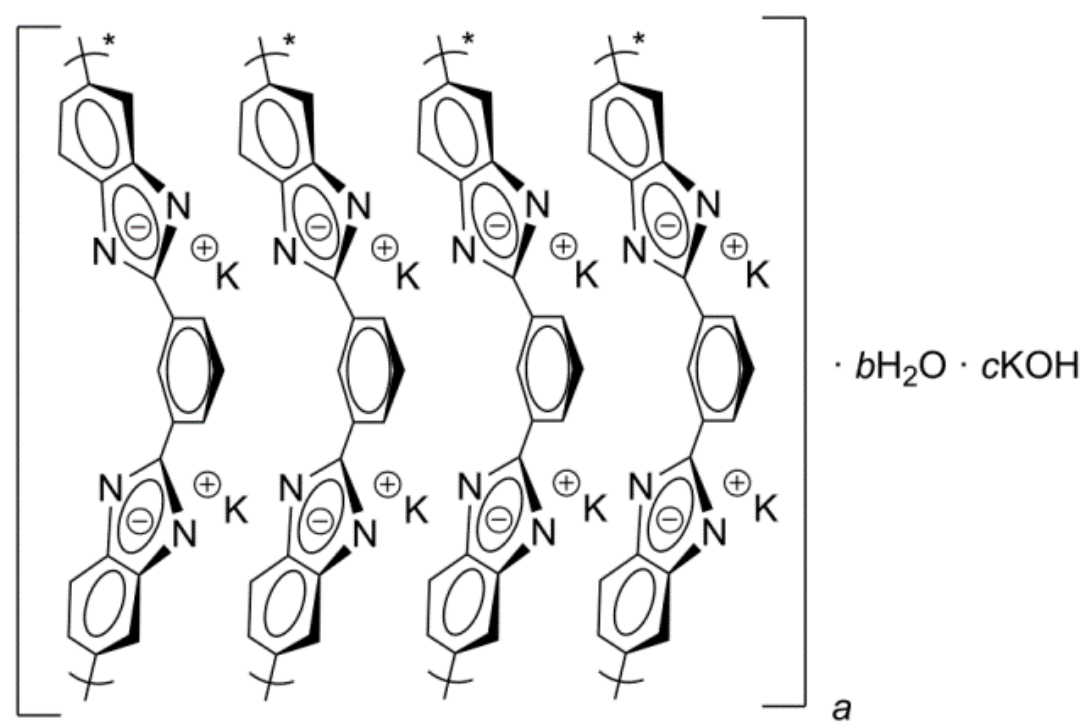

Figure 8 Schematic illustration of poly(potassium (2,2'-(m-phenylene)-5, 5'-bisbenzimidazolide)) hydrate (four polymer repeat units arbitrarily chosen) with the potassium ions located between the planes of the benzimidazole moieties.

\section{Conclusions}

When poly(2,2'-( $m$-phenylene)-5,5'-bisbenzimidazole $)$ is equilibrated in aqueous potassium hydroxide it undergoes complete ionization when the $\mathrm{KOH}$ concentration of the bulk solution reaches $15-20 \mathrm{wt} . \%$. It results in released intermolecular hydrogen bond interactions, which in turn allows for extensive volume swelling causing dramatic plasticization and increase of the ion conductivity. Further increasing the $\mathrm{KOH}$ concentration of the bulk solution to $50 \mathrm{wt} . \%$ results in reduced water content of the polymer 
matrix, inducing significant crystallization of a poly(potassium (2,2'-(m-phenylene)-5,5'bisbenzimidazolide)) hydrate as evidenced by X-ray diffraction, increased density and enhanced elastic modulus.

\section{Acknowledgments}

This work was financially supported by the Danish Council for Independent Research, Technology and Production Science (grant number 11-117035/FTP) and DTU Energy.

\section{References}

[1] T.S. Chung, A critical review of polybenzimidazoles: Historical development and future R\&D, J. Macromol. Sci. Part C: Rev. Macromol. Chem. Phys. C37 (1997) 277-301.

[2] H. Vogel, C.S. Marvel, Polybenzimidazoles, new thermally stable polymers, J. Polym. Sci. 50 (1961) 511-539.

[3] Y. Iwakura, Y. Imai, K. Uno, Polyphenylenebenzimidazoles, J. Polym. Sci. Part A 2 (1964) 26052615.

[4] N.W. Brooks, R.A. Duckett, J. Rose, I.M. Ward, J. Clements, An n.m.r. study of absorbed water in polybenzimidazole, Polymer 34 (1993) 4038-4042.

[5] C.B. Shogbon, J.L. Brousseau, H.F. Zhang, B.C. Benicewicz, Y.A. Akpalu, Determination of the molecular parameters and studies of the chain conformation of polybenzimidazole in DMAc/LiCl, Macromolecules 39 (2006) 9409-9418.

[6] R. Bouchet, E. Siebert, Proton conduction in acid doped polybenzimidazole, Solid State Ionics 118 (1999) 287-299. 
[7] J.S. Wainright, J.T. Wang, D. Weng, R.F. Savinell, M. Litt, Acid-doped polybenzimidazoles - A new polymer electrolyte, J. Electrochem. Soc. 142 (1995) L121-L123.

[8] Q. Li, R.H. He, R.W. Berg, H.A. Hjuler, N.J. Bjerrum, Water uptake and acid doping of polybenzimidazoles as electrolyte membranes for fuel cells, Solid State Ionics 168 (2004) 177-185.

[9] C.E. Hughes, S. Haufe, B. Angerstein, R. Kalim, U. Mahr, A. Reiche, M. Baldus, Probing structure and dynamics in poly[2,2 '-( $m$-phenylene)-5,5 '-bibenzimidazole] fuel cells with magic-angle spinning NMR, J. Phys. Chem. B 108 (2004) 13626-13631.

[10] S. Suarez, N. Kodiweera, P. Stallworth, S. Yu, S.G. Greenbaum, B.C. Benicewicz, Multinuclear NMR study of the effect of acid concentration on ion transport in phosphoric acid doped poly(benzimidazole) membranes, J. Phys. Chem. B 116 (2012) 12545-12551.

[11] F. Conti, A. Majerus, V. Di Noto, C. Korte, W. Lehnert, D. Stolten, Raman study of the polybenzimidazole-phosphoric acid interactions in membranes for fuel cells, Phys. Chem. Chem. Phys. 14 (2012) 10022-10026.

[12] A.K. Perry, L.K. More, E. Andrew Payzant, R.A. Meisner, B.G. Sumpter, B.C. Benicewicz, A comparative study of phosphoric acid-doped m-PBI membranes, J. Polym. Sci. Part B: Polym. Phys. 52 (2014) 26-35.

[13] K. Shirata, S. Kawauchi, Effect of benzimidazole configuration in polybenzimidazole chain on interaction with phosphoric acid: A DFT study, J. Phys. Chem. B 119 (2015) 592-603.

[14] G. Nawn, G. Pace, S. Lavina, K. Vezzù, E. Negro, F. Bertasi, S. Polizzi, V. Di Noto, Interplay between composition, structure, and properties of new $\mathrm{H}_{3} \mathrm{PO}_{4}$-doped $\mathrm{PBI}_{4} \mathrm{~N}-\mathrm{HfO}_{2}$ nanocomposite membranes for high-temperature proton exchange membrane fuel cells, Macromolecules 48 (2015) 1527. 
[15] M.K. Daletou, M. Geormezi, E. Vogli, G.A. Voyiatzis, S.G. Neophytides, The interaction of $\mathrm{H}_{3} \mathrm{PO}_{4}$ and steam with PBI and TPS polymeric membranes. A TGA and Raman study, J. Mater. Chem. A 2 (2014) 1117-1127.

[16] J.H. Liao, Q.F. Li, H.C. Rudbeck, J.O. Jensen, A. Chromik, N.J. Bjerrum, J. Kerres, W. Xing, Oxidative degradation of polybenzimidazole membranes as electrolytes for high temperature proton exchange membrane fuel cells, Fuel Cells 11 (2011) 745-755.

[17] D. Aili, A. Vassiliev, J.O. Jensen, T.J. Schmidt, Q. Li, Methyl phosphate formation as a major degradation mode of direct methanol fuel cells with phosphoric acid based electrolytes, J. Power Sources 279 (2015) 517-521.

[18] J. Weber, K.-D. Kreuer, J. Maier, A. Thomas, Proton conductivity enhancement by nanostructural control of poly(benzimidazole)-phosphoric acid adducts, Adv. Mater 20 (2008) 2595-2598.

[19] S.C. Kumbharkar, M.N. Islam, R.A. Potrekar, U.K. Kharul, Variation in acid moiety of polybenzimidazoles: Investigation of physico-chemical properties towards their applicability as proton exchange and gas separation membrane materials, Polymer 50 (2009) 1403-1413.

[20] J.S. Yang, Q.F. Li, L.N. Cleemann, C.X. Xu, J.O. Jensen, C. Pan, N.J. Bjerrum, R.H. He, Synthesis and properties of poly(aryl sulfone benzimidazole) and its copolymers for high temperature membrane electrolytes for fuel cells, J. Mater. Chem. 22 (2012) 11185-11195.

[21] F. Mack, K. Aniol, C. Ellwein, J. Kerres, R. Zeis, Novel phosphoric acid-doped PBI-blends as membranes for high-temperature PEM fuel cells, J. Mater. Chem. A 3 (2015) 10864-10874.

[22] M.J. Sansone, Crosslinking of polybenzimidazole polymer with divinyl sulfone, US Patent 4666996 (1987). 
[23] M. Hu, E.M. Pearce, T.K. Kwei, Modification of polybenzimidazole: Synthesis and thermal stability of poly( $\mathrm{N}_{1}$-methylbenzimidazole) and poly $\left(\mathrm{N}_{1}, \mathrm{~N}_{3}\right.$-dimethylbenzimidazolium) salt, J. Polym. Sci. Part A: Polym. Chem. 31 (1993) 553-561.

[24] H.T. Pu, G.H. Liu, Synthesis and solubility of $\operatorname{poly}(N$-methylbenzimidazole $)$ and $\operatorname{poly}(N$ ethylbenzimidazole): control of degree of alkylation, Polym. Int. 54 (2005) 175-179.

[25] S.C. Kumbharkar, U.K. Kharul, $N$-substitution of polybenzimidazoles: Synthesis and evaluation of physical properties, Eur. Polym. J. 45 (2009) 3363-3371.

[26] S.C. Kumbharkar, U.K. Kharul, Investigation of gas permeation properties of systematically modified polybenzimidazoles by $N$-substitution, J. Membr. Sci. 357 (2010) 134-142.

[27] O.D. Thomas, K.J.W.Y. Soo, T.J. Peckham, M.P. Kulkarni, S. Holdcroft, Anion conducting poly(dialkyl benzimidazolium) salts, Polym. Chem. 2 (2011) 1641-1643.

[28] D. Henkensmeier, H.J. Kim, H.J. Lee, D.H. Lee, I.H. Oh, S.A. Hong, S.W. Nam, T.H. Lim, Polybenzimidazolium-based solid electrolytes, Macromol. Mater. Eng. 296 (2011) 899-908.

[29] H.-J. Lee, J. Choi, J.Y. Han, H.-J. Kim, Y.-E. Sung, H. Kim, D. Henkensmeier, E. Ae Cho, J.H. Jang, S.J. Yoo, Synthesis and characterization of poly(benzimidazolium) membranes for anion exchange membrane fuel cells, Polym. Bull. 70 (2013) 2619-2631.

[30] H. Cho, E. Hur, D. Henkensmeier, G. Jeong, E. Cho, H.J. Kim, J.H. Jang, K.Y. Lee, H.A. Hjuler, Q. Li, J.O. Jensen, L.N. Cleemann, meta-PBI/methylated PBI-OO blend membranes for acid doped HT PEMFC, Eur. Polym. J. 58 (2014) 135-143.

[31] O.D. Thomas, K. Soo, T.J. Peckham, M.P. Kulkarni, S. Holdcroft, A stable hydroxide-conducting polymer, J. Am. Chem. Soc. 134 (2012) 10753-10756.

[32] A.G. Wright, S. Holdcroft, Hydroxide-stable ionenes, ACS Macro Lett. 3 (2014) 444-447. 
[33] D. Henkensmeier, H. Cho, M. Brela, A. Michalak, A. Dyck, W. Germer, N.M.H. Duong, J.H. Jang, H.-J. Kim, N.-S. Woo, T.-H. Lim, Anion conducting polymers based on ether linked polybenzimidazole (PBI-OO), Int. J. Hydrogen Energy 39 (2014) 2842-2853.

[34] B. Xing, O. Savadogo, Hydrogen/oxygen polymer electrolyte membrane fuel cells (PEMFCs) based on alkaline-doped polybenzimidazole (PBI), Electrochem. Commun. 2 (2000) 697-702.

[35] D. Aili, K. Jankova, Q. Li, N.J. Bjerrum, J.O. Jensen, The stability of poly(2,2'-(m-phenylene)-5,5'bibenzimidazole) membranes in aqueous potassium hydroxide, J. Membr. Sci. 492 (2015) 422-429.

[36] H. Zarrin, G. Jiang, G.Y.Y. Lam, M. Fowler, Z. Chen, High performance porous polybenzimidazole membrane for alkaline fuel cells, Int. J. Hydrogen Energy 39 (2014) 18405-18415.

[37] L. Zeng, T.S. Zhao, L. An, G. Zhao, X.H. Yan, A high-performance sandwiched-porous polybenzimidazole membrane with enhanced alkaline retention for anion exchange membrane fuel cells, Energy Environ. Sci. 8 (2015) 2768-2774.

[38] H. Hou, G. Sun, R. He, B. Sun, W. Jin, H. Liu, Q. Xin, Alkali doped polybenzimidazole membrane for alkaline direct methanol fuel cell, Int. J. Hydrogen Energy 33 (2008) 7172-7176.

[39] H. Hou, S. Wang, Q. Jiang, W. Jin, L. Jiang, G. Sun, Durability study of KOH doped polybenzimidazole membrane for air-breathing alkaline direct ethanol fuel cell, J. Power Sources 196 (2011) 3244-3248.

[40] A.Y. Leykin, O.A. Shkrebko, M.R. Tarasevich, Ethanol crossover through alkali-doped polybenzimidazole membrane, J. Membr. Sci. 328 (2009) 86-89.

[41] A.D. Modestov, M.R. Tarasevich, A.Y. Leykin, V.Y. Filimonov, MEA for alkaline direct ethanol fuel cell with alkali doped PBI membrane and non-platinum electrodes, J. Power Sources, 188 (2009) 502-506. 
[42] R.N. Couto, J.J. Linares, KOH-doped polybenzimidazole for alkaline direct glycerol fuel cells, J. Membr. Sci. 486 (2015) 239-247.

[43] D. Aili, M.K. Hansen, R.F. Renzaho, Q. Li, E. Christensen, J.O. Jensen, N.J. Bjerrum, Heterogeneous anion conducting membranes based on linear and crosslinked $\mathrm{KOH}$ doped polybenzimidazole for alkaline water electrolysis, J. Membr. Sci. 447 (2013) 424-432.

[44] J.O. Jensen, D. Aili, M.K. Hansen, Q. Li, N.J. Bjerrum, E. Christensen, A stability study of alkali doped PBI membranes for alkaline electrolyzer cells, ECS Trans. 64 (2014) 1175-1184.

[45] K. Matsumoto, T. Fujigaya, H. Yanagi, N. Nakashima, Very high performance alkali anionexchange membrane fuel cells, Adv. Funct. Mater 21 (2011) 1089-1094.

[46] T. Fujigaya, C. Kim, K. Matsumoto, N. Nakashima, Palladium-based anion-exchange membrane fuel cell using KOH-doped polybenzimidazole as the electrolyte, ChemPlusChem 79 (2014) 400-405.

[47] H. Zarrin, J. Fu, G. Jiang, S. Yoo, J. Lenos, M. Fowler, Z. Chen, Quaternized graphene oxide nanocomposites as fast hydroxide conductors, ACS Nano 9 (2015) 2028-2037.

[48] Section 5: Concentrative properties of aqueous solutions: Density, refractive index, freezing point depression, and viscosity, in: W.M. Haynes (Ed.), CRC Handbook of Chemistry and Physics, 93rd Edition, CRC Press/Taylor and Francis, Boca Raton, Internet Version 2013.

[49] G. Merle, M. Wessling, K. Nijmeijer, Anion exchange membranes for alkaline fuel cells: A review, J. Membr. Sci. 377 (2011) 1-35.

[50] M. Tuckerman, K. Laasonen, M. Sprik, M. Parrinello, Ab initio molecular dynamics simulation of the solvation and transport of hydronium and hydroxyl ions in water, J. Chem. Phys. 103 (1995) 150161. 
[51] L. Zeng, T.S. Zhao, L. An, G. Zhao, X.H. Yan, Physicochemical properties of alkaline doped polybenzimidazole membranes for anion exchange membrane fuel cells, J. Membr. Sci. 493 (2015) 340348.

[52] R.H. He, Q. Li, A. Bach, J.O. Jensen, N.J. Bjerrum, Physicochemical properties of phosphoric acid doped polybenzimidazole membranes for fuel cells, J. Membr. Sci. 277 (2006) 38-45.

[53] P. Staiti, F. Lufrano, A.S. Aricò, E. Passalacqua, V. Antonucci, Sulfonated polybenzimidazole membranes - preparation and physico-chemical characterization, J. Membr. Sci. 188 (2001) 71-78.

[54] D. Aili, L.N. Cleemann, Q. Li, J.O. Jensen, E. Christensen, N.J. Bjerrum, Thermal curing of PBI membranes for high temperature PEM fuel cells, J. Mater. Chem. 22 (2012) 5444-5453.

[55] E. Salmon, S. Guinot, M. Godet, J.F. Fauvarque, Structural characterization of new poly(ethylene oxide)-based alkaline solid polymer electrolytes, J. Appl. Polym. Sci. 65 (1997) 601-607.

[56] Q. Li, J.O. Jensen, R.F. Savinell, N.J. Bjerrum, High temperature proton exchange membranes based on polybenzimidazoles for fuel cells, Prog. Polym. Sci. 34 (2009) 449-477.

[57] L. Mandelkern, The structure of crystalline polymers, Acc. Chem. Res. 23 (1990) 380-386.

[58] G. Guerra, S. Choe, D.J. Williams, F.E. Karasz, W.J. MacKnight, Fourier transform infrared spectroscopy of some miscible polybenzimidazole/polyimide blends, Macromolecules 21 (1988) 231234.

[59] P. Musto, F.E. Karasz, W.J. MacKnight, Fourier transform infra-red spectroscopy on the thermooxidative degradation of polybenzimidazole and of a polybenzimidazole/polyetherimide blend, Polymer 34 (1993) 2934-2945.

[60] P. Musto, F.E. Karasz, W.J. MacKnight, Hydrogen bonding in polybenzimidazole/polyimide systems: a Fourier-transform infra-red investigation using low-molecular-weight monofunctional probes, Polymer 30 (1989) 1012-1021. 
[61] J. Yang, D. Aili, Q. Li, Y. Xu, P. Liu, Q. Che, J.O. Jensen, N.J. Bjerrum, R. He, Benzimidazole grafted polybenzimidazoles for proton exchange membrane fuel cells, Polym. Chem. 4 (2013) 47684775. 